\title{
MANHAJ FIQH SALAFI-LITERAL EKSPLORASI, KRITIK DAN APRESIASI
}

\author{
Miftahul Huda \\ Fakultas Syariah IAIN Mataram \\ Email:miftahuda09@gmail.com
}

\begin{abstract}
In the midst of various thoughts and applications of shariah in social life, and due to the historical momentum in nowadays, the method (manhaj) of literal-salafi is one of the most highlighted, appreciated and criticized aspects, both in theoretical and practical perspectives. This article is aimed to explore and describe systematically some aspects of such a method and then put them on the critical analysis framework in the epistemological and sociohistorical perspectives. Such a method has really its own superiorities and attraction in certain aspects, especially in theological and ideological views. That is due to the more consistent reference to the main sources of Islamic law, the Qur'an and the Sunnah. But in another side, there are weaknesses that should not be ignored, both in epistemological and sociological view. Those weaknesses have really been existed in its fundamental paradigms, doctrines, and also because such a manhaj has not yet been sufficiently developed in detail and practical concepts.
\end{abstract}

Keywords: Salafi, literal, manhaj, ïtihäd, naș.

DOI: http://dx.doi.org/10.20414/ ujis.v19i1.1253

\section{Pendahuluan}

SEBELUM Rasulullah Saw. wafat, kaum muslimin tidak mengalami kesulitan untuk memahami ajaran Islam, dan untuk menyelesaikan perbedaan pemahaman di antara mereka, karena semua dapat diklarifikasi kepada beliau. Apalagi saat itu jumlah mereka belum terlalu besar dan domisili mereka juga belum terpencar di berbagai negeri yang saling berjauhan.

Namun setelah Rasulullah wafat, mereka segera memasuki fase di mana tidak ada lagi rujukan yang sepenuhnya otoritatif, dan selalu siap untuk menjelaskan dan menyelesaikan perbedaan

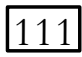


pendapat di antara mereka. Apalagi setelah terjadi perluasan wilayah pengaruh Islam pada masa Khalifah Umar bin Khattab (634-644 M) dan domisili mereka berpencar ke berbagai negeri yang saling berjauhan. Sejak itu dan seterusnya tampak bahwa ternyata para sahabat Rasul punya pemahaman yang berbedabeda tentang banyak hal meskipun sebelumnya mereka samasama menyertai Rasulullah Saw. dalam waktu yang cukup lama.

Sejumlah sahabat seperti 'Abdullah bin 'Umar, 'Abdullah bin 'Amr, dan sejumlah sahabat lainnya, karena didorong semangat untuk mengamalkan al-Qur'an dengan "semurni-murninya" dan keinginan meneladani kehidupan Rasul setepat-tepatnya, mereka lebih cenderung untuk memahami dan mengamalkan al-Qur'an dan uswah Rasul "apa adanya" sebagaimana termaktub secara harfiah dalam ayat al-Qur'an dan perbuatan konkret Rasulullah Saw., tanpa melakukan "rasionalisasi" dan pertimbangan kontekstual. Dengan pola pikir seperti itu mereka bermaksud menghinDār dari kesalahan pemahaman akibat keterbatasan ilmu, perbedaan sudut pandang, dorongan hawa nafsu dan pengaruh kepentingan tertentu. Di kemudian hari, pola pemahaman ini dikenal dengan istilah metode literal atau tekstual (al-manhaj al-harfi).

Sementara sahabat lainnya seperti 'Umar, Uthman, 'Ali, Ibn Mas'ud, dan para sahabat lainnya, seperti terlihat dari pandangan mereka mengenai berbagai hal, mereka cenderung memahami dan mengamalkan ajaran al-Qur'an dan uswah Rasul tidak selalu secara harfiah melainkan dengan pola pikir yang lebih rasional dengan mempertimbangkan sisi-sisi konteks penerapan dan implikasinya. Pemahaman seperti ini di kemudian hari populer dengan istilah metode Kontekstual. Misalnya Khalifah Umar bin Khațab yang dengan pertimbangan kontesktual memutuskan untuk tidak lagi memberikan bagian harta zakat kepada para muallaf (warga masyarakat yang baru masuk Islam) padahal teks al-Qur'an secara eksplisit menyatakan hal itu (Qs. al-Tawbah [9]: 60).

Khalifah Umar juga memutuskan tanah-tanah di wilayah yang penguasanya dikalahkan dan menjadi pampasan perang (ganimah) di Persia tetap dikelola penduduk lokal (pemilik semula) dengan mengenakan "pajak" (jizyah) atas hasil bumi 
yang mereka peroleh dan tanpa mengharuskan mereka masuk Islam terlebih dahulu. ${ }^{1}$ Padahal dalam pernyataan literal alQur'an Qs. al-Anfāl [8]: 41) dan praktek yang ada sejak jaman Rasul tanah seperti itu dibagikan kepada pasukan yang ikut dalam ekspedisi dan sebagian menjadi milik umat (negara). Kebijakan lainnya adalah keputusan untuk tidak menghukum sejumlah pencuri sekalipun dalam al-Qur'an (Qs. al-Māidah [5]: 38) secara eksplisit ada perintah melakukan hukuman itu.

Kebijakan khalifah Umar tersebut memancing protes termasuk dari sejumlah sahabat nabi yang terkemuka, karena dalam pandangan mereka Khalifah Umar telah khilaf dan membuat keputusan yang tidak tepat karena menyalahi "ajaran" nabi sebagaimana yang mereka pahami. Namun khalifah Umar atas dasar argumen dan pemahamannya sendiri terhadap ajaran Rasul, tetap bersikukuh dengan kebijakan-kebijakannya itu. ${ }^{2}$

Terlepas dari sikap setuju atau tidak setuju terhadap kebijakan Khalifah Umar tersebut, contoh-contoh di atas sudah cukup menunjukkan bahwa sekalipun para sahabat sama-sama pernah hidup bersama Rasul dalam waktu yang cukup lama, mendengar apa yang disabdakan, melihat apa yang dilakukan dan pada masa itu pula al-Qur'an diwahyukan, namun sepeninggal Rasulullah SAW mereka banyak berbeda pendapat mengenai apa sesungguhnya pesan utama yang dikehendaki oleh Rasul dalam banyak "teks" kata-kata dan tindakannya. Di lingkungan sosialnya yang baru tersebut, para sahabat menghadapi dan merespons situasi dan banyak masalah sosial yang baru berdasarkan pemaknaan, pemahaman dan "persepsi" masingmasing mengenai inti ajaran Rasulullah Saw. ${ }^{3}$

1Muhammad Abū Zahrah, Tārìkh al-Madhāhib al-Islämiyyah wa al-'Aqāìd wa Tärïkh al-Madhāhib al-Fiqhiyyah (Kairo: Dār al-Fikr al-'Arabi, t.th.).Muhammad Abū Zahrah, Tärīkh al-Madhāhib al-Islämiyyah wa al-'Aqä'id wa Tärikeh al-Madhāhib al-Fiqhiyyah (Kairo: Dār al-Fikr al-'Arabi, t.th), 233.

2Penjelasan luas mengenai argumen Khalifah Umar atas kebijakannya ini, lihat Amiur Nuruddin, Ijtihad Umar bin Khattab Studi tentang Perubahan dalam Hukum Islam (Jakarta: Rajawali Press, 1991), 137-66. Mengenai kebijakan lainnya, lihat juga Munawir Syadzali, Ijtihad Kemanusiaan (Jakarta: Paramadina, 1997), 37-43.

${ }^{3}$ Asghar Ali Engineer, Islam dan Pembebasan (Yogyakarta: LkiS, 1993), 26. Lihat Juga Muhammad Sa'īd Ramaḍan Al-Būṭị, Al-Salafyyyah Marhalah 
Dalam contoh-contoh di atas juga tampak bahwa Khalifah Umar bin Khațab memahami dan menerapkan al-Qur'an dengan pilihan fokus perhatian (angle) dan argumen yang berbeda dari sahabat yang lain karena beliau sangat menonjolkan pertimbangan tujuan hukum dan "spirit" sosiomoral dari suatu teks keagamaan (al-nașs al-shar'iyyah) dan tidak hanya terpaku pada makna harfiahnya. ${ }^{4}$ Karena jika ayat tersebut dipahami dan diterapkan secara general menurut makna harfiahnya di semua tempat, waktu dan situasi, justru akan banyak merugikan nilainilai etika syariat yang lebih substansial, seperti rasa keadilan, empati, dan ikhtiar meningkatkan kesejahteraan umat secara keseluruhan.

Setelah berlalunya masa sahabat, dua pola pemaham tersebut (pola literal dan kontekstual), kemudian sama-sama berkembang dalam dua tradisi besar pemikiran hukum Islam sekalipun tidak selalu dalam bentuknya yang ekstrem,: pertama di lingkungan Abl Hadith yang pusatnya di Madinah dan menjadi pelanjut tradisi pemikiran literal. Sedangkan yang kedua adalah kelompok Abl Ra'yz yang pusatnya di Kufah (Irak) sebagai pelanjut tradisi pemikiran kontekstual. dari dua tradisi besar inilah kemudian mengalir berbagai arus pemikiran hukum Islam sepanjang sejarahnya dari yang kukuh berpegang pada makna literal, atau yang cenderung memililih metode kontekstual maupun yang berupaya "mendamaikan" atau melakukan kombinasi di antara keduanya.

\section{Sketsa Historis Manhaj Literal}

Seperti telah dijelaskan, tradisi pemikiran hukum Islam secara literal telah berkembang sejak masa-masa awal sejarah umat Islam, yakni di tangan sejumlah sahabat nabi. Namun demikian sebagai sebuah konstruksi pemikiran Fikih, manhaj ini baru tampak lebih jelas pada pemikiran Ulama besar pendiri mazhab Hanbali, yakni Imām Ahmad bin Hanbal (164 H/ 780-

Zamāniyyah Mubārakah Là Madhhab Islāmì (Damaskus: Dār al-Fikrr, 1988), 32, 47.

${ }^{4}$ Aḥmad Amīn, Ḍubā al-Isläm (Kairo: Maktabah al-Nahḍah al-Miṣriyyah, t.th.), 238 . 
$241 \mathrm{H} /$ 855). ${ }^{5}$ Beliau adalah salah seorang ulama besar yang sebelumnya telah berguru kepada lebih dari 100 ulama di jamannya termasuk Imām Shāfi'̄, Imām Ismail bin 'Aliyyah, Imām Manșur bin Salamah, dan lain-lain. Majelis ilmu yang diasuhnya di kemudian hari juga telah menghasilkan banyak ulama besar di bidang Fikih dan Hadis, termasuk Imām Bukhari, Imām Muslim, Imām Abū Dāwūd, Imām Yazid bin Harun, dan sebagainya. ${ }^{6}$

Dalam berijtihad di lapangan fiqh Imām Ahmad bin Hanbal secara sistematis menetapkan kesimpulan hukum (istinbāt) berdasarkan dalil-dalil dan prosedur sebagai berikut:

1. Naș al-Qur'an dan Sunnah șạiḩah dalam pengertian literal. Jika telah mendapati naṣs yang memberikan penjelasan secara literal, maka beliau tidak lagi memperhatikan dalil-dalil yang lain dan juga tidak memperhatikan pendapat-pendapat sahabat yang memiliki pendapat berbeda.

2. Fatwa șahäbi yang disetujui oleh semua sahabat.

3. Pendapat sebagian sahabat. Yakni ketika para sahabat berbeda pendapat, maka beliau mengambil pendapat yang paling dekat dengan pengertian literal naș.

4. Hadis da'if dan mursal juga beliau gunakan sebagai dalil sepanjang isinya tidak bertentangan dengan pendapat sahabat.

5. Qiyàs. Dalil ini digunakan dalam porsi yang amat terbatas yakni ketika sama sekali tidak ditemukan penjelasan berdasarkan dalil-dalil yang disebutkan sebelumnya. ${ }^{7}$

Pada kurun waktu yang hampir bersamaan dengan Imām Ahmad bin Hanbal, tampil pula tokoh pemikir literal lainhya yakni Imām Dāwūd bin Khalaf al-Isbahānī yang juga dikenal

${ }^{5}$ Nama lengkapnya adalah Abū Abdillah Ahmad bin Muhammad bin Hanbal bin Hilal bin Asad bin Idris. Beliau lahir di Baghdad pada bulan Rabiul Awal 164 H (780 M) dan wafat pada bulan Rabiul Awal 241 H (855 $\mathrm{M})$.

'Syurbasi, Sejarah dan Biografi Empat Imam Mąhab (Jakarta: Hamzah, 2013), 206.

${ }^{7}$ Muhammad Sa'īd Ramaḍan Al-Būṭi, Bahaya Bebas Mą̧ab dalam Keagungan Syariat Islam (Bandung: Pustaka Setia, 2001), 304. Lihat juga Ali Hasan, Perbandingan Mą̧bab (Jakarta: Radja Grafindo Persada, 1998), 230. 
dengan Imām Dāwud al-Ẓāhīrī (200-270 H). ${ }^{8}$ Sebutan al-Ẓāhìrī dinisbatkan kepadanya untuk menegaskan karakteristik pemikirannya yang berpegang teguh pada makna literal naș (teks syariat) dan uswah (teladan) Rasul.

Imām Dāwud al-Z̄āhirī belajar ilmu fiqh dari banyak tokoh mazhab Shāfi'î, seperti Isḥaq bin Rahawaih, dan Abū Thaur. Bahkan saat itu beliau cenderung fanatik terhadap mazhab Shāfi'ì dan pernah menyusun sebuah kitab yang menjelaskan keangungan Imām Shāfi'î. Namun dalam perjalanan intelektual selanjutnya, seiring meluasnya perkembangan riwayat hadis, akhirnya beliau mengambil sikap untuk hanya menggunakan makna literal nașs saja baik dalam al-Qur'an maupun hadis, dengan menolak penggunaan teori analogi (qiyas) melalui penggalian 'illat ataupun rasionalisasi (ra'yu) untuk melakukan ta'mil.?

Menurut analisa para ahli sejarah, mazhab ini muncul sebagai respons atas perkembangan pemikiran umat Islam saat itu dimana terjadi pertentangan yang tajam di antara para pendukung ekstrem manhaj abl hadith dan abl ra'yi. Pada saat yang bersamaan, terutama di kalangan kaum Syi'ah' berkembang pula pola pikir yang bercorak batiniah di mana pemahaman terhadap nașs lebih didasarkan pada makna batin yang tersembunyi di balik teks verbalnya. Demikian pula pada saat yang bersamaan juga berkembang pengaruh pola pikir aliran Mu'tazilah yang memandang akal lebih utama sebagai sumber pengetahuan dalam memahami ajaran Islam dibandingkan dengan (makna literal) naș. ${ }^{10}$ Pada abad ke-3 dan ke-4 Hijriah mazhab Dāwūd al-Zāhirī telah menarik pengikut yang banyak dan menjadi mazhab keempat yang paling populer di dunia Islam setelah mazhab Hanafí, Mālikī dan Shāfí̀̄.

Setelah cukup lama meredup sejak wafatnya Imām Dāwūd pada paruh kedua abad ketiga hijriah, kemudian pada abad kelima hijriah, di wilayah barat dunia Islam saat itu, yakni di Andalusia, Spanyol), muncul ulama besar yang mempopulerkan

${ }^{8}$ Ensiklopedi Islam, (Jakarta: Ikhtiar Baru Van Hoeve, 1994), 220.

${ }^{9}$ Rahman Alwi, Metode Ijtihad Maz̧ab al-Zahiri Alternatif menyongsong Modernitas (Jakarta: Gaung Persada Press, 2005), 17.

10Ibid., 16. 
kembali mazhab literal, yakni Imām Ibn Hazm al-Andalusi (384456 H). ${ }^{11}$ Imām Ibn Hazm lahir dan dibesarkan di lingkungan keluarga bangsawan yang mencintai ilmu. Dalam bidang Fikih beliau tumbuh dalam tradisi intelektual mazhab Mālikī yang pada saat itu dominan di Andalusia. Karakter kritis dan penguasaan ilmu yang luas kemudian mendorongnya berpindah ke mazhab Shāfi'ì yang dinilainya lebih rasional. Namun pengembaraan intelektual selanjutnya dan semangat yang tinggi untuk terus mendalami ilmu syariat kemudian mendorongnya berpindah ke mazhab Zāhirī hingga akhir hayatnya. ${ }^{12}$

Berdasarkan pemahaman terhadap ayat-ayat al-Qur'an seperti Surah al-Māidah ayat 3 dan 67, Surah al-An'ām ayat 38, dan al-Nahl ayat 44 Imām Ibn Hazm menyimpulkan bahwa Rasulullah SAW telah menyampaikan isi agama Islam (Din alIsläm) secara utuh dan meyeluruh baik segi-segi prinsip (usul) maupun cabang-cabangnya (furū), segi lahir maupun batinnya; serta segi-segi teori ('ilm) maupu prakteknya ("amal). Oleh karena itu, pemahaman dan pengamalan ajaran Islam, seharusnya selalu merujuk pada naș dan tidak boleh ada ra'yu dalam masalah agama. Menurutnya berijtihad dengan menggunakan ra'yu berarti membuat "kebohongan" terhadap Allah SWT. Oleh karena itu Imām Ibn Hazm menentang penggunaan ra'yu dalam ijtihad seperti Qiyās, Istibsān, dan Sadd al-Dharīah.13

Namun demikian Imām Ibn Hazm berbeda pandangan dengan banyak ulama lainnya dalam hal status Hadis Ahäd. Menurutnya kedudukan hadis Mutawātir dan Ahäd secara prinsip adalah setara dan sama-sama dapat digunakan sebagai argumen (bujjah) termasuk dalam bidang 'aqidah sepanjang hadis itu diriwayatkan oleh orang-orang yang 'adil dan bersambung (sanadnya) hingga kepada Rasulullah Saw.

${ }^{11}$ Nama lengkapnya adalah 'Ali ibn Ahmad ibn Sa'id ibn HazmIbn Ghalib ibn Shalih Ibn Khalaf ibn Ma'danibn Sufyan ibn Yazid. Beliau lahir di Cordova (Spanyol) pada pagi Idul Fitri $384 \mathrm{H}$ yang bertepatan dengan 7 November 994 dan wafat pada 20 Sya’ban 456 H (15 Agustus 1064). Ibid., 29.

12Ibid., 29-37.

13Ibid., 41. 
Al-Qur'an dan hadis yang sahih merupakan kesatuan yang saling menguatkan satu sama lain, karena keduanya sama-sama bersumber dari Allah Swt. dan keduanya juga merupakan "jalan" yang mengantarkan umat manusia ke jalan Allah Swt. Namun demikian menurut Ibn Hazm, di antara semua Hadis yang ada, hanya perkataan Nabi (hadis qawli) saja yang dapat digunakan sebagai argumen hukum (bujjah), sedangkan perbuatan nabi (hadis fi'li) merupakan contoh teladan (uswah hasanah) yang tidak terlalu mengikat, sementara ketetapan Nabi (hadis taqrīr) sebatas sebagai isyarat pembolehan saja (ibāhah). ${ }^{14}$

Sepeninggal Imām Ibn Hazm, popularitas dan pengaruh manhaj literal mengalami kemunduran dalam waktu yang lama karena berbagai tantangan historis dari dinamika sosial saat itu dan karena tidak muncul tokoh ulama besar yang setara dengan beliau.

Barulah kemudian pada abad 8 Hijriah (abad ke-13 Masehi), muncul lagi seorang tokoh ulama besar, yaitu Shaykh al-Islam Ibn Taymiyah (728-861 H/1262-1328). Beliau lahir dan dibesarkan di lingkungan keluarga ulama dengan tradisi mazhab Hanbali yang kuat, kemudian melanjutkan pelajarannya kepada para ulama besar saat itu seperti Ibn 'Abd al-Qawī, Ibn 'Abd alDa'im, al-Munaj ibn Uthmān al-Tanukhī dan Ibn Qudamah. Setelah menjadi ulama, beliau mengasuh suatu majelis ilmu yang kemudian melahirkan banyak ulama besar pada generasi berikutnya seperti Ibn al-Qayyim al-Jawzī (wafat $751 \mathrm{H}$ ), Sham al-Dìn al-Dhahabī (701-748 H), Ibn Kathīr (701-774 H), 'Ilm alDīn al-Barzalī (wafat $739 \mathrm{H}$ ) dan tokoh pemikiran rasional Najm al-Dīn al-Ṭūfì (657-716 H / 1259-1316). ${ }^{15}$

Pemikiran Imām Ibn Taymiyah mengenai syariat secara umum terlihat dalam pengantar kitabnya, Ma'ärij al-IWușull, sebagai berikut:

14Ibid., 76.

15Juhaya S Praja, "Epistemologi Hukum Islam: Suatu Telaah Sumber, Illat dan Tujuan Hukum Islam Serta Metode Pengujian Kebenaran dalam Sistem Hukum menurut Ibn Taymiyah" (Disertasi, IAIN Syarif Hidayatullah, 1998), 37. Lihat pula Salāh al-dīn Maqbūl Ahmad, Da'wah Shaykeh al-Islam Ibn Taymiyah wa Atharyhà 'alā al-harakät al-Islämiyah alMu'āsirah wa Mawqif al-Khusum Minhā (Kuwayt: Dār Ibn al-Athir, t.th.), 79-80. 
Nabi Muhammad Saw. telah menjelaskan agama ini, pokok-pokok dan cabang-cabangnya, sisi lahir maupun batinya, baik segi doktrin maupun praktisnya. Segala aspek praktis agama (Islam) yang disebut sebagai cabang-cabang syariat atau hukum telah dijelaskan oleh nabi dengan gamblang. Tidak ada perintah atau larangan Allah Swt. yang tidak dijelaskan secara utuh oleh nabi karena Alah telah berfirman: Hari ini Aku telah sempurnakan agama kamu sekalian...". Firman-Nya yang lain juga menegaskan, "Sungguh Kami telah menurunkan kitab kepadamu untuk menjelaskan sehgala sesuatu dan memberikan petunjuk, rahmat serta janji kepada orang-orang yang beriman. ${ }^{16}$

Kemudian pada abad ke-12 hijriah muncul Shaykh Muhammad bin 'Abd al-Wahhāb (1115-1206 H) ${ }^{17}$ Beliau lahir dari lingkungan keluarga para ulama. Kakeknya Shaykh Sulaiman adalah salah seorang ulama yang terkenal di Nejed saat itu. Tanda-tanda kelak menjadi ulama besar telah tampak sejak kecil. Pada usia 10 tahun beliau sudah menghafal al-Qur'an. Setelah mengawali langkahnya di dunia ilmu di lingkungan keluarganya, kemudian melanjutkan belajarnya kepada para ulama besar di Mekah dan Madinah. ${ }^{18}$

Dengan mengambil inspirasi dari pemikiran-pemikiran Imām Ibn Taymiyah yang hidup lima abad sebelumnya, Shaykh Muhammad bin Abdul Wahhab menyeru kepada kaum muslimin untuk kembali kepada (makna literal) al-Qur'an dan hadis. Pemikirannya tersebut merupakan respons atas situasi sosial dan tradisi keagamaan kaum muslimin waktu itu yang dinilainya telah banyak menyimpang dari akidah yang lurus dan ajaran Islam yang murni serta karena meluasnya tradisi taqlíd kepada pendapat para ulama terdahulu,

Oleh karena itu menurutnya yang harus dilakukan adalah membangkitkan kembali tradisi ijtihäd. Pengamalan ajaran Islam 347.

16Seperti dikutip Al-Husayni, dalam Ibn Taymiyah; Adwa' al-Shariah. h.

${ }^{17}$ Beliau adalah Shaykh al-Islam Muhammad bin Abd al-Wahhab bin Sulaiman bin Ali bin Muhammad bin Muhammad bin Raysuid bin Barid bin Muhammad Bin Sharaf bin Umar. Beliau lahir 1115 H dan wafat 1206 H.

${ }^{18}$ Fahd bin Nashir bin Ibrahim Sulaiman, dalam catatan biografis Ibnu Taymiyah dalam Muhammad bin Șālih al-Uthaymin, Sharḥ Usūl al-Thalathah li Shaykh al-Islām Muḥammad bin 'A $\dot{b} d$ al-Wahbāb (Iskandāriyah: Dār al-Iman, 2001). 
juga harus dikembalikan kepada makna literal al-Qur'an, Hadis dan tradisi hidup tiga generasi awal kaum muslimin setelah Rasulullah SAW yakni para sahabat Rasul, generasi berikutnya (täbi'în) dan generasi berikutnya lagi (täbi' al-tābiüin). Tiga generasi awal setelah Rasul tersebut dikenal dengan istilah salaf al-sälih (para pendahulu yang saleh) sehingga ide ini juga dikenal dengan sebutan Salafiyyah.

Dalam memperjuangkan idenya tersebut Shaykh Muhammad bin Abdil Wahhab berkoalisi secara politik dan militer dengan salah satu penguasa lokal di Nejed pada saat itu yakni Muhammad bin al-Sa'ud untuk saling mendukung, yang pada akhirnya mengantarkan berdirinya Kerajaan Saudi Arabia yang berhaluan keislaman salafiyah literal dan memisahkan diri dari khiläfah Turki Uthmani pada saat itu.

Sejak diintroduksi kembali oleh Imām Ibn Taymiyah hingga sekarang, pesan untuk kembali kepada al-Qur'an, dan hadis, anjuran melakukan ijtihad serta ajakan mengikuti generasi salaf, telah menginspirasi dan mendorong munculnya pemikiran dan gerakan (harakah) yang amat bervariasi dari yang sangat literal hingga yang sangat rasional, dan dari yang amat ideologis hingga yang pragmatis, akibat perbedaan pilihan visi sosial, pola apresiasi terhadap nașs dan bentuk respons terhadap perkembangan kehidupan keagamaan, sosial, politik, kultur, dan peradaban.

Sekalipun para tokoh intelektual dan tokoh gerakan-gerakan tersebut mengambil inspirasi dan berangkat dari semangat yang sama dengan generasi awal umat Islam (salaf) sebagaimana yang ditekankan oleh Imām Ibn Taymiyah, namun pada era-era selanjutnya kemudian terjadi perbedaan-perbedaan pandangan dan bahkan juga pertentangan yang amat tajam di antara para tokoh intelektual dan tokoh pergerakan tersebut.

\section{Paradigma dan Manhaj Istinbat}

Pola pemahaman hukum Islam yang bertumpu pada makna literal naṣs antara lain didasarkan pada landasan pemikiran sebagai berikut:

1. Allah SWT telah menciptakan alam dan sekaligus menetapkan aturan-aturan-Nya. (Qs. al-A'raf [7] : 54) 
2. Hukum (Syariat) adalah milik Allah, sedangkan tugas setiap hamba adalah mengabdi ( ibädah) kepada-Nya (Qs. alDhāriyāt [51]: 57). Oleh karena itu sudah seharusnya respons manusia terhadap semua firman Allah adalah mendengarkan, dan menaatinya.

3. Semua aturan syariat telah dijelaskan secara lengkap dan sempurna melalui al-Kitab dan perjalanan risälah Muhammad SAW. Oleh karena itu satu-satunya akses menuju pengetahuan mengenai syariat adalah lewat penjelasan wahyu.

4. Untuk menjaga kemurniannya, teks-teks wahyu harus dipahami dan diamalkan secara zāahir (literal). ${ }^{19}$

5. Nilai-nilai kebenaran, tujuan, berkah, dan hikmah setiap elemen ajaran syariat tidak memerlukan pembuktian yang sifatnya analitis-rasional ataupun empirik, melainkan secara implisit telah terkandung dengan sendirinya dalam implementasi ajaran syariat yang telah ada.

Bertolak dari dasar pemikiran tersebut, maka hukum syariat harus disimpulkan (istinbät) dengan prosedur sebagai berikut:

1. Teks-teks verbal (ayat al-Qur'an dan Hadis-hadis Qauly) dipahami dan diamalkan berdasarkan makna harfiahnya;

2. Teks-teks non-verbal (Hadis-hadis Fi'ly, Taqriry, Shifaty dan tradisi kehidupan para salaf al-șalih), harus dikuti dan diterapkan sesuai dengan contoh konkret yang ada hingga sedetail mungkin.

3. Secara prinsip rasionalisasi dan pertimbangan kontekstual (tabdil, ta'līl, dan ta'mill) tidak diperbolehkan.

4. Jika terdapat pengertian yang masih samar mengenai bagianbagian tertentu dari ajaran syariat maka penyelesaiannya harus dikembalikan kepada pemahaman, pemikiran dan tradisi hidup para generasi awal umat Islam yang saleh (salaf al-șalih) atau tiga generasi awal umat Islam.

Berdasarkan pola pemahaman literal tersebut, seluruh ketentuan hukum Islam baik dalam aspek-aspek yang fundamental maupun hal-hal yang sifatnya teknis harus selalu

${ }^{19}$ Lihat Yusuf bin Muhammad al-Saied, Qawäid wa Dlawäbit Nasyr al'Aqidah al-Salafiyyah, artikel, tt. h. 3. 
didasarkan pada makna literal naș al-Qur'ann dan Hadis) dan contoh konkret kehidupan para salaf al-șälih dan tidak boleh didasarkan pada pertimbangan rasional atau pembuktian empirik terkait implikasi sosiologisnya atau relevansinya dengan situasi kehidupan sosial.

Pola penalaran hukum (istinbāt) seperti ini membawa konsekuensi teoretik sbb.:

1. Semua ketentuan hukum Islam disimpulkan satu untuk semuanya dan sekali untuk selamanya hingga aspek-aspek yang sifatnya teknis. Maksudnya, setiap ketentuan hukum yang telah diketahui didasarkan pada naș yang valid (șahih) dan jelas (shärih) maka secara prinsip harus dianggap berlaku secara mutlak dan final bagi segenap kaum muslimin di semua tempat, semua waktu, serta semua kondisi. Konsepkonsep pemahaman baru oleh orang-orang yang hidup belakangan setelah masa salaf al-sälih dengan perspektif yang baru pula, secara prinsip tidak dapat diterima karena termasuk dalam kategori bid'ah.

2. Secara prinsip hukum Islam tidak memerlukan pengembangan lebih lanjut karena semuanya telah dijelaskan secara sempurna dari aspek-aspek yang sifatnya fundamental hingga aspek-aspek yang sifatnya lebih teknis dan detail. ${ }^{20}$

3. Pemikiran dan pengamalan hukum Islam tidak memerlukan tambahan unsur-unsur yang berasal dari luar makna literal naș dan praktek aktual di masa kenabian dan generasi salaf alsălih. Dengan kata lain pengembangan konsep hukum Islam tidak memerlukan tambahan dari sumber-sumber materiil lain di luar makna literal al-Qur'an, Hadis dan athar (informasi tentang pendapat dan tradisi hidup para sahabat dan ulama generasi awal)

4. Panggiilan untuk menerapkan ketentuan syariat seperti disebutkan secara literal dalam naș dan teladan aktual dari para salaf al-sălih hingga selengkap-lengkapnya bersifat mutlak, tidak memerlukan pertimbangan-pertimbangan rasional, kontekstual ataupun sosiologis.

\section{Apresiasi dan Kritik}

20“'Ala’ Bakr, Malamih Ra'’siyyah lil Manbaj al-Salafì (t.t.: t.tp., t.th.), 64. 
Dalam sejarah umat Islam, tumbuh dan berkembangnya pemahaman Islam yang bercorak literal telah memberikan sumbangan yang amat penting sepanjang sejarah perkembangan pemikiran Islam, karena beberapa hal berikut:

Pertama, spirit untuk mengajak segenap kaum muslimin kembali kepada dua sumber pokok ajaran Islam, yakni al-Qur'an dan Sunnah nabi secara murni menjadi tonggak-tonggak sejarah yang penting pada setiap episode sejarah dalam ikhtiar membentengi kaum muslimin dari kemungkinan masuknya berbagai "distorsi" ajaran Islam yang otentik dan juga dari belenggu tradisi taqlid kepada para ulama besar, terutama empat ulama pendiri mazhab Fikih yang terkenal, Hanafi, Mālikī, Shāfi'̀', dan Hanbali.

Dengan tetap menaruh hormat kepada para ulama pendiri mazhab tersebut, para penganjur mazhab literal menegaskan bahwa para ulama tersebut bukanlah manusia-manusia super yang ma'sum (terbebas dari kesalahan). Oleh karena itu pendapat mereka bukanlah merupakan representasi kebenaran yang absolut dan final melainkan tetap sebagai produk ijtihad manusia biasa yang debatable (qābil li al-niqāsh) sehingga selalu tetap terbuka untuk dikaji ulang terutama berdasarkan parameter (makna literal) al-Qur'an dan Sunnah Rasul.

Di sisi lain, pesan kembali pada sumber otentik ajaran Islam juga memiliki andil yang penting dalam menghambat perkembangan pola-pola pemahaman Islam rasional-kontekstual yang cenderung "liar" sehingga berpotensi mengabaikan elan vital dan makna-makna filosofis syariah yang fundamental. Kajian historis muculnya Imām Dāwūd al-Zahiry (200-270 H), dan Imām Ibn Taymiyah (728- 861 H/1262-1328). mengisyaratkan hal itu.

Kedua, spirit untuk kembali ke otentisitas sumber ajaran Islam, kian menegaskan urgensi dokumentasi historis (kompilasi dan kodifikasi riwāyah) tentang kehidupan nabi dan generasi salaf al-ṣalih yang kemudian semakin mendororg perkembangan Ilmu Hadis, dan ilmu riwayat dengan semua pembidangan dan ilmuilmu penunjangnya. Hasil kompilasi, seleksi, dan kodifikasi hadis-hadis "sahih" dan riwayat tentang pemikiran dan tradisi para salaf al-sălih mengenai berbagai masalah ritual dan sosial 
semakin melengkapi referensi yang sudah ada sebelumnya serta sebagai rujukan tambahan dan menjadi opini pembanding (disenting opinion) dalam melakukan ijtihad mengenai berbagai masalah kehidupan.

Namun demikian, dari perspektif dan cara penilaian yang berbeda, pemahaman literal juga mengundang sejumlah keberatan dan kritik yang tidak boleh diabaikan baik secara epistemologis, historis maupun sosiologus.

\section{Kritik epistemologis}

Jumlah naṣ syariah amat terbatas dan tidak bertambah lagi setelah wafatnya Rasulullah SAW, sementara jumlah masalah yang dihadapi umat manusia tidak terbatas dan terus berkembang baik secara kuantitas maupun kualitas seiring dengan perkembangan jaman, dengan segenap kompleksitasnya. Oleh karena itu jika semua naș terutama yang terkait dengan masalah hukum, dipahami sebatas makna literalnya dan diterapkan hingga dalam aspek teknis yang sekecil-kecilnya maka akan banyak masalah yang tidak dapat direspons dan ditangani. Sementara itu jika sebagian naș dianggap hanya memberikan penjelasan general saja, maka berarti dalam pemahaman yang lebih detail dan implementasinya tetap memerlukan unsur-unsur yang berasal dari luar nașs, baik dalam elemen pemikiran maupun instrumen pelaksanaanya, dan hal itu secara teoretik sebenanrnya ditolak oleh penganjur manhaj ini,.

Di samping itu konsep pembedaan antara masalah keagamaan yang ketentuan hukumnya dibatasi hanya pada makna literal nașs hingga sekecil-kecilnya dan urusan-urusan sosial yang masih menerima perubahan-perubahan tertentu, sejauh ini belum disusun secara jelas, sistematis dan diterapkan secara konsisten $21 \mathrm{Hal}$ tersebut terkait dengan pertanyaan

${ }^{21} \mathrm{Di}$ antara argumen yang digunakan bagi pemikiran yang bersdiat dikotomik seperti ini adalah: Pertama, sabda Rasulullah SAW. "man abdatha fi amrina fa huwa raddun" (barangsiapa membuat hal baru dalam urusanku ini maka ia tertolak) di mana kata "urusanku" diartikan sebagai urusan keagamaan. Kedua, sabda Rasulullah SAW, "antum a'lamu bi umur dunyäkum" (kalian lebih mengerti mengenai urusan dunia kalian) yang dugunakan dalam urusan duniawi atau yang sifatnya non-keagamaan. Namun demikian konsep 
apakah isi suatu teks yang sabih merupakan bagian dari esensi syariat yang harus diamalkan atau hanya merupakan instrument teknis, atau hanya deskripsi fakta sosial di era kenabian, atau bahkan hanya masalah kecenderungan pribadi yang secara substansial tidak mengandung Sunnah yang wajib diikuti (alSunnab al-Muttaba'ab).

Misalnya perbedaan pandangan tentang hukum memanjangkan jenggot dan mencukur kumis, ${ }^{22}$ kepemimpinan orang Quraisy, ${ }^{23}$ menyampaikan salam dan menjelaskan sesuatu selalu diulang tiga kali, ${ }^{24}$ kepemimpinan wanita ${ }^{25}$, bertetangga atau tinggal di negeri orang kafir, ${ }^{26}$ mengenakan cincin perak di jari manis, ${ }^{27}$ membawa tongkat, ${ }^{28}$ pengobatan dengan madu, ${ }^{29}$ dll. yang terdapat dalam kitab-kitab sabih. Sekalipun dari sisi sanad banyak teks hadis sahih yang isinya terkait dengan hal-hal tersebut, namun para ulama berbeda pendapat apakah hadishadis seperti itu termasuk dalam ketentuan syariat yang wajib diamalkan "apa adanya" tanpa rasionalisasi ataukah tidak termasuk di dalamnya.

Belum disusunnya kriteria pembedaan yang jelas, dan sistematis antara wilayah keagamaan dan yang bukan wilayah keagamaan, acap kali menimbulkan sikap yang tidak konsisten dalam merespons berbagai permasalahan. Perbedaan pandangan mengenai penilaian Sunnah dan Bid'ah dalam banyak masalah sosial dan keagamaan, sebagian disebabkan oleh tidak adanya

pembedaan mengenai kedua domain tersebut sejauh ini belum berhasil disusun yang jelas, tegas dan sistematis.

${ }^{22} \mathrm{Abu}$ 'Abd Allāh Muhammad ibn Ismāîil ibn Ibrāhīm ibn al-Mughīrah ibn Bardizbah al-Ju'fì al-Bukhārī, Matn al-Bukhärì JJeddah: al-Ḥaramayn, t.th.), 38-9.

${ }^{23} \mathrm{Abū}$ al-Ḥsayn 'Asākir ad-Dīn Muslim ibn al-Hajjāij Muslim, Saḅ̂̉h Muslim (Dār Iḥyā' al-Kutub al-'Arabiyyah, t.th.), 122.

${ }^{24}$ al-Bukhārī, Matn al-Bukehārì, 29.

${ }^{25}$ Musțafā Muhammad 'Imārah, Jawāahir al-Bukhārì (Dār Ihya al-Kutub al-Arabiyyah Indonesia, 1371), 367.

26Shaykh Nașìr al-Dīn al-Albānī, al-Fatāwà al-Madinah al-Munawwarah, trans. Taqdir Muhammad Arsyad (Yogyakarta: Media Hidayah, 2004), 133.

${ }^{27}$ al-Bukhārī, Matn al-Bukhärì, 36.

${ }^{28}$ Sayyid Ahmad Hashimi, Mukhtär al-Ah̆ädith al-Nabawiyyah wa al-Hikaam al-Mubammadiyyah (Semarang: Toha Putra, t.th.), 68.

${ }^{29}$ al-Bukhārī, Matn al-Bukbārì, 9. 
konsep yang jelas dan sistematis mengenai pembedaan ini. Padahal konsep pembedaan tersebut amat penting untuk segera dirumuskan karena dalam realitas sosial kedua dimensi kehidupan tersebut (keagamaan dan keduniaan) selalu terkait satu sama lain. Di samping itu, pola pikir dikotomik antara urusan dunia dan akhirat juga berimplikasi pada kecenderungan pembatasan diskursus pemikiran syariah hanya berputar-putar pada masalah yang dianggap wilayah "keagamaan"' saja.

Argumen-argumen (bujjah) yang sepenuhnya bertumpu pada makna literal nașs secara dogmatis tanpa menyelami dan memperhatikan sisi manusiawi (bumanity), keluasan dan kedalaman tujuan sosiomoral syariat, serta konteks sosial munculnya sebuah nașs menjadikan pemahaman literal cenderung kurang "berwawasan", dan kurang sesuai dengan perkembangan alam pikiran umat manusia, serta kepentingan untuk menangani masalah-masalah sosial secara konkret dan solutif.

Pemahaman literal juga cenderung tidak memperhatikan sisi historisitas teks, seolah-olah teks-teks syariat yang ditemukan generasi sekarang, misalnya kutub al-sittah, atau yang telah dilakukan tarkhrij dan tarjīh oleh ulama tertentu merupakan produk yang validitasnya nyaris mutlak dan cenderung tidak boleh dikaji ulang. Padahal sesungguhnya teks-teks tersebut muncul, dan berkembang hingga sampai ke tangan generasi umat Islam sekarang ini melalui proses konstruksi historis yang lama dan berliku-liku di bawah pengaruh atmosfir sosiohistoris yang menyertai proses pembentukannya, serta melibatkan pilihan-pilihan perspektif para rawi, ahli hadis, dan penulis kitab dengan segenap kelebihan dan keterbatasan mereka sebagai pribadi manusia yang tidak ma'șim.

Secara konseptual seharusnya juga disadari adanya perbedaan antara respons terhadap pesan nabi di masa hidup beliau dengan suatu naș yang dibawakan oleh generasi sepeninggal beliau. Dalam penjelasan yang lebih konkret, menentang perintah nabi ketika beliau masih hidup berarti menentang nabi itu sendiri, sedangkan menolak suatu pemikiran yang disimpulkan dari suatu teks yang diklaim berasal dari sabda atau perbuatan nabi yang disampaikan oleh seorang ulama atau 
para ulama di lingkungan mazhab tertentu tidak selalu bermakna menolak ajaran nabi, karena boleh jadi penolakan itu dilakukan karena meragukan otentisitasnya, menganggapnya bukan menjadi bagian dari wilayah syariat (sekalipun sanad-nya sahih), atau karena lebih memilih teks-teks yang lain, atau karena memahami naș tersebut dengan pilihan manbaj atau perspektif lain yang dinilainya lebih tepat. Dalam hal ini pilihan sudut pandang dan metode berpikir yang berbeda akan membuka peluang terjadinya perbedaan pembacaan, apresiasi dan pemahaman terhadap suatu naṣ syariat, sekalipun terhadap naṣs yang sama.

Pola pemahaman literal yang diterapkan dalam segala hal juga cenderung tidak dapat mengakomodasi aspek-aspek yang sifatnya teknis instrumental, yang implementasinya amat bergantung pada kompleksitas masalah sosial yang direspons. Apalagi jika dalam segala hal selalu dituntut rujukan dari pernyataan atau praktek konkret pada jaman nabi atau para generasi salaf al-sălih hingga sekecil-kecilnya. Hal itu karena para generasi salaf al-sălih sendiri juga bukanlah pribadi-pribadi ma'șum yang selalu dibimbing wahyu, dan suasana tantangan kehidupan yang mereka jalani juga sudah sangat berbeda dengan kondisi di jaman nabi dan berbeda pula dengan problema sosial yang dihadapi umat Islam di masa sekarang dan yang akan datang.

Demikian pula karena pola ijtihad literal biasanya hanya membuat perbedaan hitam putih Sunnah dan Bid'ah, maka pola pikir tersebut cenderung kurang bisa mengakomodasi perspektif tentang intensitas perintah (apakah menghasilkan hukum wäjib atau sunnah) dan larangan (apakah mengarah pada hukum harām atau makrüh) yang terdapat dalam teks syariat. Misalnya hadis tentang "keharusan" adanya wali nikah terdapat dalam banyak kitab hadis sabih sehingga para ulama tidak meragukan kesahihannya. Namun para ulama berbeda pendapat apakah wali nikah itu bagian dari rukun (yang menentukan sahnya nikah) atau sebatas elemen penyempurnaan saja (sehingga tanpa wali pun nikah tetap sah sekalipun kurang sempurna). Demikian pula hukum mandi pada hari Jumat, sekalipun Imām Muslim meletakkan hadis mengenai hal itu di bawah judul bab kewajiban 
mandi Jumat (bāb wujūb gusl al-Jum'ab) ${ }^{30}$ namun sebagian besar ulama tidak menyatakan hukum wajib.

Dengan metode ijtihad literal yang bertumpu pada rujukan naș dan athar, kajian Hukum Islam akan hanya berputar-putar pada masalah-masalah lama yang mungkin sudah dibahas selama berabad-abad dan kesimpulan hukumnya juga sudah ada pada salah satu dari pendapat-pendapat yang sudah ada. Berbagai masalah sosial yang lebih urgen dan strategis pada era kontemporer dan yang diprediksi bakal terjadi di masa depan akan sulit direspons dengan manhaj ini, seperti berbagai masalah di lapangan sosial, ekonomi, politik, pendidikan, teknologi, pengobatan, demografi, lingkungan hidup, dan bahkan dalam batas tertentu juga yang terkait masalah ritual keagamaan.

Di samping itu pola pemahaman literal juga dapat berdampak pada kebekuan berpikir (jumüd) serta kesempitan wawasan sosial, keagamaan, dan keilmuan, karena pengembangan pemikiran hukum dibatasi secara ketat hingga sekecil-kecilnya oleh makna literal teks yang jumlahnya terbatas dan pemahaman-pemahaman para ulama generasi salaf yang pada tingkat tertentu sebenarnya juga "diproduksi" oleh dinamika sejarah, format tatanan sosial, wawasan sosial para rawi, dan situasi langit sejarah yang menyertai proses pembentukannya.

\section{Kritik bistoris}

Secara historis, pemahaman para sahabat nabi terhadap alQur'an dan Sunnah nabi sejak awal sebenarnya sudah terbagi ke dalam dua pola yaitu yang literal dan yang non-literal, Oleh karena itu klaim bahwa semua sahabat nabi dan segenap generasi salaf al-sălih semuanya berpegang pada makna literal al-Qur'an dan Hadis, tidaklah sesuai dengan fakta sejarah sekalipun sejumlah pernyataan mereka sering digunakan sebagai argumen untuk melegitimasi klaim tersebut. ${ }^{31}$

Telah dijelaskan bahwa pola pikir non-literal juga sudah ada sejak masa awal umat ini bersamaan dengan munculnya

${ }^{30}$ Muslim, Sabīh Muslim, 337.

${ }^{31}$ Ahmad Farid, Al-Salafiyyah Qawä'd wa Ushulh. 16 
pemikiran literal. ${ }^{32}$ Pengenalan tradisi baru șalat tarawih ${ }^{33}$ dan berbagai kebijakan Khalifah Umar tentang muallaf, ganimah, hukuman pencuri yang telah disebutkan di atas, pemakaian stanDār mashaf Uthmani dalam bacaan al-Qur'an dan tradisi dua kali adzan pada șalat Jumat pada masa Khalifah Uthman, pengenaan hukuman 80 kali cambuk bagi peminum khamar oleh Khalifah Ali, dll adalah hanya sebagian kecil dari banyak contoh fakta sejarah, di mana para sahabat juga telah sepakat untuk mengamalkan sejumlah pemahaman yang tidak sepenuhnya literal, padahal mereka mengetahui bahwa semua itu tidak diamalkan di masa Rasulullah SAW. Kajian luas atas pendapat para sahabat dalam masalah furü iyyah akan semakin banyak menemukan pemahaman mereka terhadap al-Qur'an dan uswah Rasulullah SAW yang tidak sepenuhnya bersifat literal. Hal itu berarti dalam pandangan mereka, amalan-amalan tersebut tetap berada di jalan kebenaran dan tidak bertentangan dengan isi alQur'an dan Sunnah Rasulullah SAW.

Setelah generasi sahabat berlalu, para ulama generasi berikutnya juga menggunakan pola pemikiran yang tidak seluruhnya bercorak literal seperti yang terlihat pada pola pikir kalangan Abl al-Hadis dan Abl al-Ra;"yi Pengenalan ide tentang sumber-sumber sekunder sebagai pelengkap seperti Istibsān oleh Imām Hanafi, al-Maṣlahah al-Mursalah dan 'Amal Abl al-Madinah oleh Imām Mālikī, Qiyās oleh Imām Syafii (dan dalam porsi terbatas juga oleh Imām Ahmad bin Hanbal), ${ }^{34}$ praktek Shalat

32Al-Būṭ̄, al-Salafiyyah Marbalah, 18.

33Terkait dengan Shalat Tarāwih, Khalifah Umar bin Khattab memulai tradisi baru dalam tiga hal. Pertama, melaksanakannya setelah shalat Isya dan tidak lagi dimulai pada tengah malam. Kedua, menyatukan semua jamaah pada satu imam, yang sebelumnya dilakukan secara sporadis yang dilakukan sendiri-sendiri atau dalam kelompok-kelompok kecil. Ketiga menetapkan jumlah rakaatnya sebanyak 20 rakaat, padahal para sahabat sebelumnya memiliki pendapat yang bermacam-macam. Terhadap hasil ijtihad Khalifah Umar ini ternyata tidak ada penolakan oleh sahabat lainnya padahal hampir semua sahabat senior waktu itu masih hidup, termasuk ummul mukminin 'Aisyah RA yang sebagian riwayat haditsnya digunakan sebagai argumen bagi pendapat yang berbeda dengan Khalifah Umar bin Khatab tersebut.

${ }^{34}$ Wahbah al-Zuhaylī, Ușūl al-Fiqh al-Islāmì (Damaskus: Dār al-Fikr, 1986), 734. 
Tarawih sebanyak 36 rakaat pada masa Khalifah Umar bin Abdul Aziz dari Daulah Bani Umayyah, dan berbagai pendapat para ulama setelah generasi sahabat menunjukkan bahwa dalam memahami naș al-Qur'an dan Hadis, para ulama salaf tersebut tidak selalu membatasi diri hanya pada makna literalnya. Seandainya makna literal teks telah memadai untuk menjawab segala masalah hukum hingga dalam masalah yang sekecilkecilnya tentu para ulama tersebut tidak mengembangkan sumber-sumber sekunder, karena keberadaan sumber sekunder itu tidak diperlukan.

Oleh karena itu klaim bahwa semua ulama generasi salaf alșălih selalu memahami dan mengamalkan naṣs al-Qur'an, dan Sunnah secara literal dalam segala hal, adalah klaim yang tidak benar dan bertentangan dengan fakta sejarah, sekalipun sejumlah pernyataan mereka sering dijadikan argumen bahwa mereka berpola pikir literal.. Yang benar adalah bahwa baik pola pemahaman literal maupun non-literal semuanya sama-sama memiliki pijakan epistemologis dan dasar-dasar pemikiran yang telah ada sejak masa generasi salaf al-șälih.

\section{Kritik sosiologis}

Pemahaman dan penerapan nașs tanpa melihat konteks sosialnya akan menemui banyak masalah yang sifatnya sosiologis. Generalisasi makna naș secara mutlak tanpa melihat konteks sosialnya dapat mendorong pemahaman dan penerapan makna al-Qur'an dan Hadis yang bukan pada tempatnya, bertentangan dengan spirit etik fundamentalnya, serta tidak menghasilkan pemikiran yang solutif terhadap masalah kehidupan. Hal itu juga akan cenderung melahirkan sikap apologis, hipokrit, dan pilih-pilih yang tidak sistematis dalam penerapan teks, serta menimbulkan inkonsistensi para penganjur manhaj ini antara ranah wacana, dengan pengamalannya dalam kehidupan sehari-hari.

Pemahaman literal yang bertumpu pada idealiasi dan upaya membawa pemahaman dan penerapan hukum Islam ke masa lalu hingga dalam masalah yang kecil-kecil menjadikan pola pikir para ulama cenderung hanya bersifat reaktif dan bukan proaktif, karena dengan pola pikir seperti itu mereka akan terus melihat 
banyak fenomena sosial sekarang ini yang tidak sesuai lagi dengan makna literal naș dan praktek konkret generasi awal umat Islam (salaf al-sālib).

Ada lagi yang perlu dicatat, adanya teks-teks (nașs) yang telah dinilai sahih berdasarkan parameter tertentu sering menimbulkan persepsi, dan klaim-klaim kebenaran eksklusif, serta kecenderungan merasa benar sendiri, yang acap kali menumbuhkan sikap sektarian, eksklusif, arogan, dan bahkan “agresif' terhadap pihak lain yang berbeda pendapat. Hal itu karena adanya persepsi (yang keliru) bahwa pemahaman yang didasarkan pada teks sabih selalu memiliki nilai kebenaran yang absolut dan final sehingga segenap kaum muslimin harus mengikuti pendapat tersebut dan meninggalkan pendapatpendapat lainnya. Padahal sebenarnya penilaian "sabib" itu sendiri dan juga kesimpulan hukum hasil istinbät terhadap nas.s yang sahih tersebut tetaplah hasil ijtihad dari pribadi-pribadi ulama yang tidak dijamin bebas dari kesalahan (ma'sum) dan semuanya amat bergantung pada pilihan naș yang dipakai sebagai hujjah, pilihan pijakan epistemologis dan metode istinnbät. yang tidak sepenuhnya sempurna. Oleh karena itu kesimpulannya juga tidak akan pernah memiliki nilai kebenaran yang absolut dan final.

Persepsi tentang kemutlakan validitas teks berdasarkan metode tertentu (misalnya melalui kritik sanad) dan kemutlakan kebenaran kesimpulan hukum dari teks-teks yang dinilai sahīh tersebut pada gilirannya akan cenderung menghilangkan semangat kritik ilmiah yang amat diperlukan dalam pengembangan ilmu Fikih, mengubah majelis-majelis ilmu menjadi forum indoktrinasi sektarian, menutup kembali pintu ijtihad dan mendorong umat (termasuk para ulamanya) terperosok kembali dalam semangat fanatisme sektarian dan taqlìd kepada para ulama terdahulu, misalnya fanatik kepada Imām Ahmad bin Hanbal, Imām Ibn Taymiyah, atau Imām Ibnl Qayyim al-Jauziyah,, suatu keadaan yang dulunya justru dikritik keras oleh para ulama tersebut, khususnya oleh Imām Ibn Taimiyah sendiri.

Seperti dikemukakan Hassan Hanafi, pemikiran keagaman umat Islam pada umumnya bertumpu pada model "upaya 
pengalihan teks ke dalam realitas" seakan-akan teks adalah realitas yang dapat "berbicara" sendiri. Menurutnya, pandangan semacam itu mengandung sejumlah kelemahan mendasar yang antara lain:

a. Teks adalah teks dan bukan realitas. Ia hanyalah deskripsi linguistik atas realitas yang (oleh karenanya, secara kualitas) tidak dapat menggantikannya. Dan karena setiap argumentasi haruslah otentik maka penggunaan teks sebagai argumentasi seharusnya juga merujuk pada otentisitasnya dalam realitas.

b. Berbeda dengan rasio atau eksperimen yang memungkinkan manusia mengambil peran untuk menentukan (validitasnya), teks justru menuntut kepercayaan apriori terlebih dahulu, sehingga argumentasi teks hanya mungkin bagi orang yang percaya dan menerima (terlebih dahulu).

c. Teks bertumpu pada otoritas al-Kitab bukan pada otoritas rasio. Padahal otoritas seperti itu tidaklah argumentatif karena dalam kenyataannya terdapat banyak sekali versi pilihan teks dan penafsiran teks yang sama-sama diambil dari) Kitab Suci sementara otoritas rasio hanya satu.

d. Teks adalah bukti (al-burbān) yang "asing". Ia datang dari luar dan tidak datang dari dalam realitas. Padahal dalam pembuktian, keyakinan yang datang dari luar selalu lebih lemah dari pada yang datang dari dalam.

e. Teks (seharusnya) selalu terkait dengan acuan realitas yang ditunjuknya. Tanpa acuan ini teks menjadi tidak bermakna dan bahkan akan menyelewengkan maksud sesungguhnya dari teks-teks yang ada, sehingga bisa terjadi salah paham serta aplikasi teks yang tidak pada tempatnya.

f. Teks pada prinsipnya adalah unilateral yang selalu terkait dengan teks-teks lainnya. Sehingga tidak mungkin untuk beriman hanya kepada satu (bagian dari) Kitab dengan mengingkari yang lain, karena hal itu hanya akan menjebak para penafsirnya ke dalam pola pikir yang parsialistik.

g. (Dalam memilih sebagai rujukan atau dalil) Teks-teks selalu dalam ambiguitas pilihan yang tidak luput dari pertimbangan untung-rugi. (Sebagai contoh) Seorang kapitalis akan memilih teks-teks yang sedapat mungkin dapat melegitimasi kepentingannya, sebagaimana seorang sosialis juga akan 
melakukan hal yang sama teradap teks-teks lainnya. Demikian pula seseorang yang cenderung pro atau anti paham Mu'tazilah, akan berargumentasi dengan memilihmilih teks yang sesuai dengan kecenderungannya itu. Di sini sesungguhnya yang menjadi penentu bukanlah teks itu melainkan kepentingan dan kecenderungan penafsirnya. Teks hanya digunakan untuk memberikan legitimasi dan justifikasi terhadap apa yang sudah ada (sudah dipilih) sebelumnya

h. Posisi sosial seorang penafsir menjadi basis bagi pilihannya terhadap teks (dan interpretasinya). Sehingga, di dalam realitas, perbedaan dan pertikaian di antara para penafsir akan menjadi sumber pertikaian masyarakat.

i. Teks hanya berorentasi kepada keimanan, emosi keagamaan dan sebagai pemanis dalam apologi para pendukungnya, tetapi tidak mengarah pada rasio dan kenyataan dalam hidup keseharian mereka. Oleh karena itu pendekatan tekstual bukanlah metode ilmiah yang cocok untuk menganalisa realitas (dan problematika yang dihadapi) kaum muslimin melainkan hanya sebuah model apologetik untuk memperjuangkan kepentingan suatu golongan atau sistem tertentu untuk melawan pihak lain. Padahal apologi nilainya jauh lebih rendah dari pada pembuktian.

j. Metode tekstual lebih cocok untuk dijadikan sebagai nasihat dari pada pembuktian karena sebagai prinsip ia hanya memperjuangkan ajaran Islam, tetapi tidak memperjuangkan nasib kaum muslimin sebagai sebuah komunitas.

k. Kalaupun mengarah pada realitas, metode teks maksimal hanya akan memberikan penjelasan tentang status tetapi tidak menjelaskan perhitungan kuantitatif. 35

\section{Penutup}

dari uraian di atas dapat digarisbawahi bahwa jika dilihat dari berbagai sudut pandang, akan tampak bahwa di samping

${ }^{35}$ Kazuo Shimogaki, Kiri antara Islam Modernisme dan Post-modernisme Telaah Kritis atas Pemikiran Hassan Hanafi (Yogyakarta: LkiS, 1993). Dalam edisi ini terjemahan teks asli Hassan Hanafĩ dilampirkan lengkap pada bagian belakang. 
memiliki sejumlah kelebihan yang amat penting, manhaj literal juga memiliki sejumlah kekurangan yang tidak dapat diabaikan.

Berbagai argumen yang dibangun untuk mendukung manhaj ini, pada umumnya sebatas menjelaskan pentingnya mengikuti al-Qur'an, Hadis dan generasi salaf, (yang secara prinsip sebenarnya juga telah diterima oleh segenap kaum muslimin), namun belum memberikan argumen dan elaborasi yang cukup luas, dan mendalam tentang kelebihan metode literal itu sendiri dan keharusan untuk selalu menggunakan metode literal dalam mengikuti al-Qur'an, Hadis dan tradisi generasi salaf tersebut.

Semangat dan ajakan untuk kembali kepada ajaran Islam otentik yang menjadi latar historis dan spirit moral dari manhaj ini merupakan pesan abadi bagi segenap kaum muslimin dengan argumen keagamaan yang kokoh. Namun demikian suatu konsep pemikiran tidak akan memadai jika hanya berupa paradigma fundamental saja, karena secara prinsip hal itu juga telah diterima oleh umat Islam secara umum.

Paradigma tersebut memerlukan konsep-konsep aplikasi yang dikonstruksi secara sistematis, terpadu, dan operasional. Dan pada bagian terakhir inilah manhaj literal belum dikembangkan secara optimal hingga kini, khususnya elaborasi yang terkait dengan masalah historisitas nașs, pembagian wilayah keagamaan dan yang bukan, cara memahami dan memilah-milah antara pesan utama, sisi-sisi historis dan teknis dari makna sebuah naṣs serta konsep bentuk respons terhadap perkembangan kehidupan masyarakat di berbagai aspek kehidupan. Wa Allāh a'lam bi al-ṣawāb

\section{Daftar Pustaka}

'Imārah, Musțafā Muhammad. Jawāhir al-Bukhārì Dār Ihya alKutub al-Arabiyyah Indonesia, 1371.

Abū Zahrah, Muhammad Tärikeh al-Madhähib al-Islämiyyah wa al'Aqāid wa Tärïkh al-Madhāhib al-Fiqhiyyah. Kairo: Dār al-Fikr al-'Arabi, t.th.

Ạ̣mad, Șalāḥ al-dīn Maqbūl. Da'wah Shaykh al-Islam Ibn Taymiyah wa Atharyhà 'alā al-ḥarakàt al-Islämiyah al-Mu'ạsirah wa Mawqif al-Khusum Minhā. Kuwayt: Dār Ibn al-Athir, t.th. 
al-Albānī, Shaykh Naṣīr al-Dīn. al-Fatāwā al-Madinah alMunawwarah. Translated by Taqdir Muhammad Arsyad. Yogyakarta: Media Hidayah, 2004.

al-Bukhārī, Abū 'Abd Allāh Muḥammad ibn Ismāc̄il ibn Ibrāhīm ibn al-Mughīrah ibn Bardizbah al-Ju'fi. Matn al-Bukhäri. Jeddah: al-Haramayn, t.th.

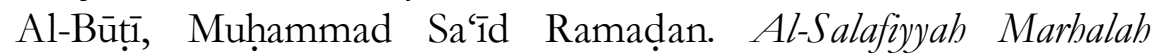
Zamāniyyah Mubārakah Là Madhbab Islāmì. Damaskus: Dār alFikr, 1988.

------. Bahaya Bebas Mazhab dalam Keagungan Syariat Islam. Bandung: Pustaka Setia, 2001.

al-Uthaymin, Muhammad bin Șāilh. Sharḥ Ușūl al-Thalathah li Shaykeh al-Isläm Muhammad bin 'Abd al-Wahhäb. Iskandariyah: Dār al-Iman, 2001.

al-Zuhaylī, Wahbah. Ușūl al-Figh al-Islāmì. Damaskus: Dār alFikr, 1986.

Alwi, Rahman. Metode Ijtihad Maz̧ab al-Zabiri Alternatif menyongsong Modernitas. Jakarta: Gaung Persada Press, 2005.

Amīn, Aḥmad. Duhā al-Islām. Kairo: Maktabah al-Nahḍah alMișriyyah, t.th.

Anonymous, Ensiklopedi Islam. Jakarta: Ikhtiar Baru Van Hoeve, 1994.

Bakr, 'Ala'. Malāmìh Ra'īsiyyah lil Manhaj al-Salafì. t.t.: t.tp., t.th.

Engineer, Asghar Ali. Islam dan Pembebasan. Yogyakarta: LkiS, 1993.

Hasan, Ali. Perbandingan Mað̧ab. Jakarta: Radja Grafindo Persada, 1998.

Hashimi, Sayyid Aḥmad. Mukhtär al-Aḥädìth al-Nabawiyyah wa alHikeam al-Muhammadiyyah. Semarang: Toha Putra, t.th.

Muslim, Abū al-Ḥusayn 'Asākir ad-Dīn Muslim ibn al-Hajjāj. Saḥ̣̄̄ Muslim. Dār Ihyāà' al-Kutub al-'Arabiyyah, t.th.

Nuruddin, Amiur. Ijtihad Umar bin Khattab Studi tentang Perubahan dalam Hukum Islam. Jakarta: Rajawali Press, 1991.

Praja, Juhaya S. "Epistemologi Hukum Islam: Suatu Telaah Sumber, Illat dan Tujuan Hukum Islam Serta Metode Pengujian Kebenaran dalam Sistem Hukum menurut Ibn Taymiyah." Disertasi, IAIN Syarif Hidayatullah, 1998. 
136 Llumunz, Vol. 19, No. 1 (June) 2015

Shimogaki, Kazuo. Kiri antara Islam Modernisme dan Post-modernisme Telaah Kritis atas Pemikiran Hassan Hanafi. Yogyakarta: LkiS, 1993.

Syadzali, Munawir. Ijtihad Kemanusiaan. Jakarta: Paramadina, 1997.

Syurbasi. Sejarah dan Biografi Empat Imām Mą̧hab. Jakarta: Hamzah, 2013. 